University of Nebraska - Lincoln

DigitalCommons@University of Nebraska - Lincoln

Faculty Publications, Classics and Religious

Studies Department

June 1994

\title{
Distorted Mirrors: Antonius Margaritha, Johann Buxtorf and Christian Ethnographies of the Jews
}

Stephen G. Burnett

University of Nebraska - Lincoln, sburnett1@unl.edu

Follow this and additional works at: https://digitalcommons.unl.edu/classicsfacpub

Part of the Classics Commons

Burnett, Stephen G., "Distorted Mirrors: Antonius Margaritha, Johann Buxtorf and Christian Ethnographies of the Jews" (1994). Faculty Publications, Classics and Religious Studies Department. 63.

https://digitalcommons.unl.edu/classicsfacpub/63

This Article is brought to you for free and open access by the Classics and Religious Studies at DigitalCommons@University of Nebraska - Lincoln. It has been accepted for inclusion in Faculty Publications, Classics and Religious Studies Department by an authorized administrator of DigitalCommons@University of Nebraska - Lincoln. 


\title{
Distorted Mirrors: Antonius Margaritha, Johann Buxtorf and Christian Ethnographies of the Jews
}

\author{
Stephen G. Burnett \\ University of Nebraska-Lincoln
}

\begin{abstract}
Antonius Margaritha's Entire Jewish Faith (1530) and Johann Buxtorf's Jewish Synagogue (1603) were the two most influential Christian ethnographies of the Jews written during the early modern period. Margaritha and Buxtorf were not disinterested ethnographers who sought to provide a balanced and fair appraisal of Jewish life and religion, but were Christians who were violently opposed to Judaism, and their descriptions were to some degree skewed by their theological and social agendas. They criticized Judaism and the Jews from three different perspectives: Judaism as a biblical theology, the social interaction of ordinary Jews and Christians, and Jewry as an order within the political world of the German empire. These portrayals of the Jews and their religion together with the responses of Jewish leaders and intellectuals shed light upon the most important lines of Jewish-Christian theological conflict in early modern Germany.
\end{abstract}

WHEN JOHANN PFEFFERKORN began to write anti-Jewish pamphlets that included descriptions of the religious rites and practices of his former brethren, he turned a new page in the history of anti-Jewish polemics. ${ }^{1}$ Instead of arguing over how specific biblical passages should be interpreted, he and his successors criticized the very foundation of Jewish life by attacking halakic observance of the 613 commandments (mitzvot) together with other religious and social customs followed by their Jewish contemporaries. Mocking the hopes, beliefs, and religious practices of ordinary German Jews was a new and menacing development in polemical writing, particularly since these works tended to be written in German rather than Latin, and thus had a wide potential readership. Pfefferkorn employed vignettes from

${ }^{1}$ At about the same time another Cologne Jewish convert, Victor of Carben, wrote Dem durchleuchtigsten hochgebornen fursten und herren herre Ludwign Phalzgrauen bey rein ... Hier inne wirt gelesen wie Her Victor von Carben, Welicher eyn Rabi der Juden gewest ist zu Christlichem glawbn komen ... (n.p., 1508/1509). See Willehad Paul Eckert, "Hoch- und Spätmittelalter. Katholischer Humanismus," in: Kirche und Synagoge: Handbuch zur Geschichte von Christen und Juden. Darstellung mit Quellen, ed. Karl Heinrich Rengstorf and Siegfried von Kortzfleisch, 2 vols. (Stuttgart: Ernst Klett, 1968-1970), 1:252, 257,280 .

This article is a revision of "Distorted Mirrors: Johann Buxtorf and the Jewish Ethnographic Tradition," presented at the Sixteenth Century Studies Conference, Atlanta, Georgia, October 1992. Research for this article was supported in part by a Research Assistance Grant from the American Academy of Religion. 
Jewish life and customs in his polemical tracts. His books Jewish Confession (Judenbeicht, 1508) and Easter Booklet (Osterbüchlein, 1509) are the best-known examples of theological ethnography, but there are incidental references to Jewish customs in several of his other books as well. ${ }^{2}$ However, Pfefferkorn's use of ethnographic exempla was both haphazard and tendentious. It was his younger contemporary Antonius Margaritha who set the literary standard for ethnographic discussion of the Jews in his book The Entire Jewish Faith (Augsburg, 1530). Building upon Margaritha's work, Johann Buxtorf's The Jewish Synagogue (Basel, 1603) ultimately became the definitive representative of this genre.

Margaritha and Buxtorf were not disinterested ethnographers who sought to provide a balanced and fair appraisal of Jewish life and religion, but were Christians who were violently opposed to Judaism, and their descriptions were to some degree skewed by their theological and social agendas. ${ }^{3}$ However, their portrayals of observant Jewish life are sufficiently accurate and detailed to give at least a semblance of objectivity. By presenting their works as mirrors of Jewish life and behavior these two writers provided implicit characterizations of Jews and Judaism for their Christian readers that were both plausible and potentially dangerous for German Jewry. These portrayals of the Jews and their religion together with the responses of Jewish leaders and intellectuals shed light upon the most important lines of Jewish-Christian theological conflict in early modern Germany, providing examples of the kind of anti-Jewish polemics the Jews could safely ignore and those they felt compelled to answer.

Margaritha's Entire Jewish Faith was an ambitious attempt to describe Jewish life from cradle to grave. He not only discusses rites of passage, the commandments which governed Jewish life throughout the year, and a number of other customs practiced both at home and in public, but he also provides a translation of the prayer book into German in the second part of the book, together with a running commentary on the synagogue service. Margaritha's goal was not to satisfy the curiosity of Christians, but to expose Judaism as an unbiblical religion that posed a danger to the Christian faith. His book served as a pattern for many subsequent anti-Jewish polemics, most notably for Johann Buxtorf's Jewish Synagogue.

Buxtorf was familiar with the existing literature of Jewish ethnographies, having read at one time or another books by Victor of Carben, Pfefferkorn, Ernst Ferdinand Hess, and Margaritha. ${ }^{4} \mathrm{He}$ structured the ethnographic part of Jewish

${ }^{2}$ For example, Pfefferkorn mentions Jewish pilgrimages to the tomb of R. Meir ben Baruch of Rothenburg in Worms; see Johann Pfefferkorn, In lob und eer dem Allerdurchleuchtigsten Großmechtigsten Fursten und heren hern Maximilian (Köln: Heinrich von Neuß, 1510), fols. C4r-v. See Hans-Martin Kirn, Das Bild vom Judentum im Deutschland des frühen 16. Jahrhunderts, Texts and Studies in Medieval and Modern Judaism, no. 3 (Tübingen: J. C. B. Mohr [Paul Siebeck], 1989), 56.

${ }^{3}$ In describing these books as "ethnographies of the Jews" I am adopting an interpretive category suggested by R. Po-chia Hsia in his paper "Christian Ethnographies of Jews," presented at the conference "The Expulsion of the Jews: 1492 and After," University of California at Davis on April 2, 1992.

${ }^{4}$ Buxtorf read and took notes on Victor of Carben, Opus aureum ac novum et a doctis viris diu expectaum (Cologne, 1509), and Johann Pfefferkorn, In laudem et honorem Illustrissimi maximique principi .... . (Cologne: Heinrich von Neuss, 1510). See Basel UB MS A XII 20, pp. 271-79, 265-67. Buxtorf, Juden Schul (Basel: Sebastian Henricpetri, 1603), 127 and 572-73, also quotes from Ernst Ferdinand Hess, Flagellum Iudaeorum. Juden Geissel (Erfurt: Martin Wittel, 1599), the latter without attribution. 
Synagogue according to the pattern found in the Entire Jewish Faith, dividing his discussion into three parts: daily commandments and customs, feasts and fasts, and private and public practices; he ended his book with a section on the Messiah and the world-to-come. Buxtorf also quoted frequently from Margaritha's book in Jewish Synagogue, and may even have derived the title of his work from Margaritha's, judging from their wording. ${ }^{5}$ However, these similarities mask very different assessments of the Jews and their religion.

Before considering the contrasting portraits of Jews and Judaism that emerge from Margaritha and Buxtorf, we must consider the theological conventions implicit in most ethnographies of the Jews. ${ }^{6}$ Nearly all of these books drew an explicit contrast between so-called biblical Judaism and the degenerate rabbinical Judaism of their contemporaries. The Jews were not good people who "strictly and zealously" obeyed the law of Moses. Instead, they obeyed the teachings of the rabbis, who had altered the Mosaic law at many points, introduced many of their own innovations, and "scandalously" misinterpreted the word of God. ${ }^{7}$ Christians were not to view the Jews with scorn, but rather to think of them as an object lesson of what happens whenever God's people ignore and disobey him. ${ }^{8}$ Finally, these authors claimed that they wrote their books in order to convince the Jews to convert to Christianity. ${ }^{9}$ These three points form a coherent theological agenda which also had social implications for German Jewry, since the Jews constituted not only a religious minority, but also a separate nationality within the German empire.

The Jewish ethnographies of Margaritha and Buxtorf reflect Christian criticism of the Jews at three different levels: Judaism as a biblical theology, the social interaction of ordinary Jews and Christians, and Jewry as an order within the political world of the German empire. Margaritha's religious critique of Judaism focused on its departure from biblical norms. He noted that the Jews had started

${ }^{5}$ Buxtorf, Juden Schul, 294-98, 361, 398, 510, 573, 599, 614. On the similarity of the two titles, see Mark R. Cohen, "Leone da Modena's Riti:A Seventeenth Century Plea for Social Toleration of the Jews." Jewish Social Studies 34 (1972): 294, n. 36.

${ }^{6}$ I consulted the following works for this analysis:Victor of Carben, Juden Büchlein. Hyerinne wirt gelesen/wie herr Victor von Carben/welcher ein Rabi der Jüden geweßt its/zu Christlichem glauben kommen (n. p., 1550), which is a reprint of Dem durchleuchtigsten hochgebornen fursten; Johann Pfefferkorn, Osterbüchlein (Cologne: [Johannes Landen], 1509), and idem, Juden Spiegel (Cologne: [Martin von Werden], 1508, reprinted in Kirn, Bild, 205-30); Antonius Margaritha, Der Gantz Jüdisch Glaub (Augsburg: Heynrich Steyer, 1530); Hess, Juden Geissel; and Buxtorf, Juden Schul.

${ }^{7}$ See Carben, Juden Büchlein, fols. D6v-7v; Pfefferkorn, Osterbiichlein, fols. C1 r-3v; Margaritha, Gantz Jüdisch Glaub, fol. A2v; Hess, Juden Geissel, fols. G1 r-v; and Buxtorf, Juden Schul, fols. ):(5v-6r, 663. Medieval theologians began to distinguish between "biblical Judaism" and "rabbinical Judaism" (based upon the Talmud) in the thirteenth century. See Jeremy Cohen, The Friars and the Jews: The Evolution of Medieval Anti-Judaism (Ithaca: Cornell University Press, 1982), 68-69, passim.

${ }^{8}$ Margaritha, Gantz Jüdisch Glaub, fol. A; and Buxtorf, Juden Schul, fol. ):(7r. Both Luther and Eck read Margaritha's book and adopted this theological theme in their own anti-Jewish writings. Kirn, Bild, 198. Augustine argued that the fate of the Jews should serve as a warning to Christians in the opening lines of his Adversus Judaeos, chap. 1, printed in J. P. Migne, ed. Patrologia Latina (Paris: Siron; Vrayet, 1844-64), vol. 42, col. 51.

${ }^{9}$ See Carben, Juden Büchlein, fol. A2r, and the Christian-Jewish disputation reprinted later in his book; Pfefferkorn, Juden Spiegel, fol. d2v = Kirn, Bild, 227; Margaritha, Gantz Jüdisch Glaub, fol. A3v; Hess, Juden Geissel, fol. N7 r-v; and Buxtorf, Juden Schul, fol. )7r. 
with the Bible and had written "large books," the tractates of the Talmud, on how to observe the law properly. ${ }^{10}$ Despite these lengthy discussions the Jews managed to misinterpret the plain sense of scripture on numerous occasions. One example which Margaritha found especially egregious was the Capporah ceremony. On the day before Yom Kippur, the Day of Atonement, Jews ritually slaughtered chickens, one for each member of the household, roosters for men, and hens for women. The most frequent justification given for sacrificing a chicken was that the word Geber meant "man" in Hebrew and "rooster" in Talmudic Aramaic. One Geber must die for the sins of another. ${ }^{11}$ Margaritha wrote scornfully, "Listen to me you blind Jew and not to your Talmud, which has hidden the truth from you with a chicken. A chicken cannot bear your sins. A person has sinned and a person must bear the $\sin . " 12$ It is only fair to note at this point that a number of influential rabbis, most notably Moses Nahmanides and Joseph Karo, also thought that the Capporah was a "silly custom." 13 Margaritha described the numerous rabbinic innovations introduced in the centuries since Jesus' death variously as "childish," "foolish," "superstitious," or as a form of "sorcery." 14 The Jews had clearly departed from the revelation given to them in the Bible. Despite this they continued to believe that they were still the apple of God's eye and were certain that they would inherit the earth, while all other peoples would experience God's judgment. ${ }^{15}$ In Margaritha's opinion, the pride and arrogance engendered by this belief made them a danger to both individual Christians and to the social order as a whole.

Individual Christians experienced Jewish arrogance firsthand in their dealings with Jews, according to Margaritha. When Christians borrowed money from Jewish moneylenders they became in effect servants of the Jews. ${ }^{16}$ Other Christians literally served Jewish masters on the Sabbath, working for them in order to help them circumvent their own laws. ${ }^{17}$ These master-servant relationships served to reinforce the Jews' own natural sense of superiority. Jewish contempt for Christians was also expressed directly when they cursed Christians to their face. For example, Margaritha claimed that the Jews intentionally mispronounced the greeting "Seyt Gott will komm," meaning "welcome" to "Sched will komm," meaning "here comes a devil." 18 Margaritha also reported a particularly vivid example of a curse that was connected with the Capporah ceremony on the day before Yom Kippur. Some Jewish men were not wealthy enough to afford chickens for every member of their household-or they simply preferred to spend their money on carousing.

${ }^{10}$ Margaritha, Gantz Jïdisch Glaub, fols. C2r, D1 v-3r, F4v, H1 v.

${ }^{11}$ Ibid., fols. E2v-3v.

12“"Höre hie zu blinder Jude und nicht deinem Talmudt der dir hie mit dem hanen die warhait vertuncklet hatt. Ein han kan deine Sund nicht ertragen. Ein person mus sollich sund widerumb auffheben." Ibid., fol. E4r.

${ }^{13}$ Joshua Tractenberg, Jewish Magic and Superstition: A Study in Folk Religion (New York: Behrman's Jewish Book House, 1939), 163-64.

${ }^{14}$ Ibid., fols. C4r, D2r, E1 v, F4v, H3r.

${ }^{15}$ Ibid., fol. F3r-v.

${ }^{16}$ Ibid., fol. J3v

${ }^{17}$ Ibid., fol. C1 v.

${ }^{18}$ Ibid., fol. B4r. The word shed in Hebrew means "evil spirit" or "devil." 
These men would wait by their house door or in the streets for an ignorant Christian to come along. They would then ask the Christian, "Would you be my Capporah? I will pay you one or two pennies if you will." Margaritha interpreted this transaction to be a symbolic transfer of sins, that the Jew said in essence: "I have sinned and deserve to die.You go in my place, bear my sin, die in my stead." 19 Margaritha felt that both the exercise of authority by Jews and the malice that they expressed toward Christians in day-to-day interaction was intolerable in a Christian society, and he believed that these conditions reflected the inappropriately high status of the Jews within the German empire.

Margaritha also attacked the political status of German Jewry as an order within the Holy Roman Empire. According to him, the Jews blasphemed the Christian faith daily in their prayers and prayed seditiously for the overthrow of their Christian rulers. ${ }^{20}$ While these charges were hardly news to theologians, Margaritha's German translation of the prayer book made it far simpler for lay people to learn of these unacceptable prayers. ${ }^{21}$ The Jews violated imperial law simply by practicing their religion. ${ }^{22}$ The indulgent Jewish policies pursued by both the emperor and lesser princes made life easier for the Jews, confirming them in their good opinion of themselves and their religion. The Jews considered their wealth, their ability to exercise power through usury, and the friendliness of some Christians toward them to be important "compensations" in their exile. ${ }^{23}$ Consequently, Margaritha called upon Germany's rulers to forbid usury and to force the Jews to engage in manual labor to earn their living. ${ }^{24}$

Margaritha considered the Jews to be a thoroughly misguided and dangerous religious community within the empire. Apart from their crude and inaccurate

19“'Auch an etlichen ordten wo sie nit hanen finden künden, nemen sie ein fisch, welliche aber arm seind, oder sonst gerinnge leut die das gelt lieber verzechen stellen sich unnder jhr hauss thür oder warten auff der gassen biss etwan einn einfeltiger Christ kompt, zu den sprechen sie wistu mein capporah sein so wil ich dir ain pfenning oder zwen schencken, sit aber als vil geredt also woldt der Jude sprechen ich sol sterben, hab gesündiget, fare du für mich hinn, trage du meyne sünde, stirbe du für much, \& etc." Ibid., fols. E3r-v.

${ }^{20}$ Ibid. Blasphemous prayer: fols. W4r-X1r. Prayer for overthrow of Magistrate: Q4v-R1r.

${ }^{21}$ Many of these prayers were translated into Latin after the disputation of Paris in 1240, and some governments even tried to suppress parts of the Jewish liturgy. See Yosef Hayim Yerushalmi, "The Inquisition and the Jews of France in the Time of Bernard Gui," Harvard Theological Review 63 (1970): 35463, esp. 359, n. 100.

${ }^{22}$ Margaritha implied that by tolerating these abuses the emperor and the princes invited the wrath of God upon themselves as accomplices to blasphemy. See Robert v. Hippel, Deutsches Strafrecht, vol. 1: Allgemeine Grundlagen (Berlin: Julius Springer, 1925), 215, n. 1. The legal definition and treatment of blasphemy in Reichspolizeiordnungen is discussed by J. Segall, "Geschichte und Strafrechte der Reichspolizeiordnungen von 1530, 1548, und 1577," Strafrechtliche Abhandlungen (Breslau) 183 (1914): 144-57. On the importance of these Polizeiordnungen, see Gerhard Oestreich, "'Police' and Prudentia civilis in the seventeenth century," in: idem, Neostoicism and the Early Modern State, ed. Brigitta Oestreich and H. G. Koenigsberger, tr. David McLintock, Cambridge Studies in Early Modern History (Cambridge: Cambridge University Press, 1982), 155-61. Luther made this point quite explicitly in Von den Juden ihren Lügen, reprinted in D. Martin Luthers Werke. Kritische Ausgabe (Weimar: Böhlau, 1883-1988), 53:531.34-532.6 (hereafter abbreviated as WA).

${ }^{23}$ Margaritha, Gantz Jïdisch Glaub, fols. a4 $\mathrm{r}-\mathrm{v}$.

${ }^{24}$ Ibid., fols. J3 r-v, K1 r-2v. 
interpretations of the Bible and ungodly way of life they loathed Christianity and Christians, expressing this hatred in any way that they could. In addition, they enjoyed a special protected status within the empire that allowed them to live in peace and comfort. With all of the zeal of a convert Margaritha sought to expose the dangers that Jews posed for his fellow Christians and petitioned the rulers of Germany to reconsider their Jewish policies. Since Margaritha was the son of a prominent rabbi, Samuel b. Jacob Margolis of Regensburg, his description of Judaism was accorded great authority by Catholic and Protestant readers alike, which in turn gave great weight to his anti-Jewish calumnies. ${ }^{25}$ It was in fact Margaritha's "political" charges which made his book such a sensation and resulted in a summons from Emperor CharlesV for him to dispute with Josel of Rosheim at the Diet of Augsburg in $1530 .{ }^{26}$

Buxtorf's Jewish Synagogue, although it was patterned after Margaritha's book, presents a very different portrait of Jews and Judaism. Buxtorf's concern was to provide a theological critique of Judaism, not to call for social and political changes in the status of the Jews. In order to help the reader to see and understand the significance of the Jewish customs he related, Buxtorf devoted his first chapter to creating a theological lens. After a brief examination of the "Jewish Creed"Maimonides'Thirteen Articles ${ }^{27}$-Buxtorf analyzed what he considered the most important theological difference between Christianity and Judaism: their sources of religious authority. In a passage that is strangely reminiscent of the Jewish "chain of tradition," Buxtorf linked the unfaithful Israelites whom Moses and the prophets opposed, the Pharisees, and the authors of the Talmud with the rabbis of his own day. ${ }^{28}$ All of these people shared a common belief that God had unconditionally chosen the Jews to be his people and had honored them above all others by giving them circumcision, the written law, the land of Israel, the temple, and the sacrificial system as outward signs of this inward election. ${ }^{29}$ Starting from these premises, however, they became convinced that outward conformity to the 613 commandments (mitzvot), which the rabbis distilled from scripture and elaborated upon first

${ }^{25}$ There is no satisfactory study of Margaritha's book as a piece of Jewish ethnography. Josef Mieses, Die älteste gedruckte deutsche Uebersetzung des jüdischen Gebetbuches a. d. Jahre 1530 und ihr Autor Anthonius Margaritha. Eine literarhistorische Untersuchung (Wien: R. Löwit, 1916), focuses on Margaritha's translation of the prayer book and his philological abilities, and was marred by the author's open hostility toward Margaritha. Mieses wrongly thought that Margaritha's ethnographic discussion was derived from Victor of Carben's Dem durchleuchtigsten hochgebornen fursten (40-49). Apart from the prayer book itself, Margaritha probably derived much of his material from Pfefferkorn's pamphlets, most notably his four woodcuts which are mirror images of those in Pfefferkorn, Juden Beicht (Cologne: Johannes Landen, 1508), fols. A2r, B1r, B2r, and B3v. Cf. Margaritha, Gantz Jüdisch Glaub, fols. E1r, E2r, E4v, and F2v. Kirn, Bild, 39, n. 101. Kirn drew several other parallels between Margaritha's book and Pfefferkorn's corpus on 47, n. 137; 56, n. 184; 98, n. 202; and 113, n. 277.

${ }^{26}$ Selma Stern, Josel of Rosheim: Commander of Jewry in the Holy Roman Empire of the German Nation (Philadelphia: Jewish Publication Society, 1965), 99-101.

${ }^{27}$ See Cecil Roth and Geoffrey Wigoder, eds., Encyclopaedia Judaica Jerusalem: Macmillan, 19711972), s.v. “Articles of Faith," by Alexander Altmann.

${ }^{28}$ Buxtorf, Juden Schul, fols. ):(5r-v. On the chain of tradition, see Gerson D. Cohen, introduction to The Book of Tradition (Sefer Ha-Qabbalah), by Abraham Ibn Daud (London: Routledge \& Kegan Paul, 1967), pp. xxviii-lxii.

${ }^{29}$ Juden Schul, 50-51. 
in the Mishnah and later in the Talmud, was the essence of maintaining their covenant relationship with God. ${ }^{30}$ In theory the rabbis considered the Talmud and the Pentateuch to be of equal authority, because the rabbis taught that both were revealed to Moses on Mount Sinai, the former in oral form and the latter in written. ${ }^{31}$ In practice, however, they lavished far more attention upon the Talmud than the Bible since the latter did not provide the detailed instructions necessary for proper observance of the commandments. ${ }^{32}$ Buxtorf thought that the Jews' definition of true piety as halakic observance based upon the precepts of the Talmud was a fundamental theological error, since he considered the Talmud to be a product of merely human reflection and not divine revelation. He felt that the teachings of the Bible and those of the Talmud were irreconcilable, and he set out to demonstrate that the Jews' religion represented not conformity with the Law of Moses, but a departure from it. After setting up the opposition between the Bible and Jewish law in his first chapter, Buxtorf repeatedly pointed out rabbinical departures from biblical revelation by contrasting biblical passages with talmudic ones. In his conclusion he asserted that Judaism was based not upon Moses, but "upon the lies and false, baseless commandments and fables of their rabbis and deceiving scribes." 33

The theological character of Jewish Synagogue was underscored by Buxtorf's treatment of the rabbis. Because they served as the theologians of Judaism, they were the focus of Buxtorf's contempt. He sarcastically referred to them throughout the book as the "most wise" rabbis, especially when relating outrageous haggadic explanations for specific laws and practices. ${ }^{34}$ To return to the Capporah, Buxtorf's reaction was similar to Margaritha's, but with a twist. Buxtorf quoted a long excerpt from an account of a medieval disputation in Solomon Ibn Verga's Shebet Yehudah where the Jewish disputant confirmed that Jews really did identify the Geber with man and chicken. His concluding comment is instructive: "We see from this what a mockery and a travesty the Jews make of the Bible, and how they prove with their deeds that they have been struck with madness, blindness, and hardness of heart as God had threatened to do through Moses," an allusion to Deut. 28:28. ${ }^{35}$ Blinded as they were to the plain words of scripture, the Jews thought that they could please God by observing the rabbis' ordinances as precisely as possible.

Buxtorf made his disapproval of the theological foundations of Judaism, many individual laws and customs, and some of the synagogue liturgy clear through his

${ }^{30}$ Ibid., 26, 40-49.

${ }^{31}$ Ibid., 60-62.

32Ibid., 56-60, 79.

${ }^{33}$ Buxtorf concluded his book by asserting that he had proved that Jewish law was based upon human wisdom, not the Bible. "Es wird aber der Christliche Leser genugsam aus disem allem vernommen und verstanden haben/ dass der judisch Glaub und ihre gantze Religion nicht auff Mosen/sonder auff eitel Lügen/ falsche und ungegründete Satzungen und Fabeln ihrer Rabbinen und weitverführten Schrifftgelehrten gegründet sey ....' Ibid., 663.

${ }^{34}$ Juden Schul, 2, 18, 26, 41, 43-45, 47, 81, 90, 96, 103, 119, 170-171, 263, passim.

35"Darauss zusehen, wie ein gespöt und gauckelwerck die Juden mit der heiligen Schrifft treiben, unnd mit der that beweisen, dass sie mit Wahnsinn, Blindheit, und verstockung des Hertzen geschlagen sind, wie jhnen Gott durch Mosen gedrewet hat." Ibid., 514. Buxtorf quoted from a Yiddish translation of the book; for the Hebrew original, see Solomon Ibn Verga, Sefer Shebet Yehudah, ed. Azriel Shochet (Jerusalem: Mossad Bialik, 1946-1947), 141-49. 
introductory chapter, with occasional sarcastic comments throughout the body of the book and through his frequent use of biblical quotations as foils to contemporary Jewish practice. In most of Jewish Synagogue, however, Buxtorf allowed Jewish authors to speak for themselves without overt editorial interference when explaining what it meant to live as a Jew. ${ }^{36}$ Since he relied primarily upon written sources to describe observant Jewish life, Buxtorf provided a portrait of Jewish life as the rabbis wished it to be rather than the way Jews actually lived. His characterization of Judaism was prescriptive rather than descriptive.

Buxtorf addressed Jewish interaction with Christians only obliquely and incidentally in Jewish Synagogue. Jewish children were not allowed to play with Christians and were taught to hate them as a part of their upbringing. ${ }^{37}$ Jewish children were said to defile meat that their elders sold to Christians. ${ }^{38}$ Adults cheated their Christian customers and sometimes cursed Christians, taking advantage of the fact that Hebrew was unknown to most non-Jews. ${ }^{39}$ Significantly, Buxtorf did not mention Margaritha's calumny that poor Jews looked for Christians to serve as their Capporah, probably because he could not confirm it in a Jewish source. He did not entirely trust the works of Jewish converts, and he tried to verify their claims by consulting the works of professing Jews whenever possible. ${ }^{40} \mathrm{He}$ pointed out that Jews never invited Christians to weddings or to the Passover meal. ${ }^{41}$ Jews were willing to take advantage of Christians as Sabbath servants in order to circumvent their own laws. ${ }^{42}$ Like Margaritha before him, Buxtorf felt that the rulers should forbid Christians to be Sabbath servants for Jews, and for the same reason: it was not right for Jews to be masters over Christians. ${ }^{43}$ These remarks, however, were

36"Quaeris praeterea, quomodo Fabulas illas judaicas contesserim. Respondeo ipsos Judaeos mihi suggessisse. Primo \& principaliter oblato libro Rituum, cui Minhagim nomen. Et qui hebraeo germanice editus est. Eum si cupis tibi dono mittam. Deinde intellexi totum illorum jus, civile \& canonicum \& quae praeterea habeat, dinim quasi Aphorismis comprehensum in libro, cui Shulhan Aruk nomen. Hunc etiam opera Judaeorum accepi. Postea Talmud ipsum \& eos, quos praeterea cito, assecuus sum, in hos animi gratia excurri, \& quicquid reperi, ad Minhagim retuli." Johannes Buxtorf to Matthias Martinius, Basel, September 4, 1606, printed in Johann Buxtorf, "Epistola Johannis Buxtorfii, P. ad Matthiam Martinium," Bibliotheca historico-philologico-theologica classis 4, fascicle 3 (1721): 601. On the contents and significance of the Shulhan Aruk, see Phillip Sigal, The Emergence of Contemporary Judaism, vol. 2: Survey of Judaism from the 7th to the 17th Centuries, Pittsburgh Theological Monograph Series, no. 12 (Pittsburgh: Pickwick Press, 1977), 319-25.The particular Minhagim book used by Buxtorf is discussed in Morris Epstein, "Simon Levi Ginzburg's Illustrated Custumal (Minhagim-Book) of Venice, 1593, and its Travels," Proceedings of the Fifth World Congress of Jewish Studies, Jerusalem, 3-11 August 1969, 4:197-218.

${ }^{37}$ Juden Schul, 152. Cohen, "Modena," 295, mentions some of Buxtorf's other sources.

${ }^{38}$ Ibid., 572-73, quoting (without attribution) a calumny from Hess, Juden Geissel, fol. L1 v.

${ }^{39}$ Ibid., 159, 547, 585.

${ }^{40}$ In the same letter Buxtorf explains what he thought of convert writings: "Is continebit Causas odii Judaeorum in omnes gentes ... non quidem illa ex scriptis baptizatorum Judaeorum quibus non semper fides habenda (italics mine); sed ex ipsissimis libris circumcisorum Judaeorum...." Buxtorf, "Epistola Johannis Buxtorfii," 601.

${ }^{41}$ Juden Schul, 427, 584.

${ }^{42}$ Ibid., 391, 584.

43"Were recht und billich, das solches von Christlicher Oberkeit verbotten, unnd der Juden keine Dienste am Sabbath und anderen Festen geleistet wurden.” Ibid., 391. 
peripheral to his concerns. ${ }^{44}$ Buxtorf never mentioned usury in Jewish Synagogue, and he referred to Jewish doctors only in passing. ${ }^{45}$ Indeed, it is unclear from Buxtorf's discussion how Jews could make enough of a living to support their elaborate ritual life. ${ }^{46}$ Although Buxtorf worked with Jews almost daily during this part of his life and must have been familiar with some of the social and economic parameters of Jewish life, he made no attempt to explain them. However, given Buxtorf's focus on ritual observance in Jewish homes and the synagogue, it is not too surprising that Christians are seldom encountered in Jewish Synagogue.

Buxtorf's discussion of Jewry as an order within the German empire is almost nonexistent. His neglect of the topic reflects a different set of political and religious considerations than those which shaped Reformation--era discussions. The early seventeenth century was a period of escalating conflict between three contending Christian confessions-Lutheranism, Calvinism, and Catholicism-each one championed by a different alliance of imperial cities and territorial states. ${ }^{47}$ While tension between Christians and Jews had not disappeared, Judaism was not a threat to these well-entrenched confessional churches. At least some German princes and magistrates became convinced that maintaining an official confession and allowing Jews to reside in their domains were not incompatible policies. ${ }^{48}$ Jewish life became far more stable under the protection of territorial princes than it had been for over a century under the emperors. ${ }^{49}$

Buxtorf apparently did not consider the Jews and their religion to be any kind of threat to the Christian political and religious order. He noted that Christian authorities were sometimes called upon to settle squabbles within Jewish communities that the Jews were unable to settle themselves. ${ }^{50}$ Significantly, he did not

${ }^{44}$ Buxtorf in fact promised to address the question of Jewish hatred and calumnies in another book, apparently his unpublished manuscript Aus was Ursachen die Juden andere völker alzeit gehasst unnd veracht haben, Basel UB MS A IX 78. See Juden Schul, 222, 460, 586.

${ }^{45}$ Juden Schul, 573.

${ }^{46}$ Cohen, "Modena," 310 , n. 133, pointed out that Buxtorf made almost no references to economic activity.

${ }^{47}$ Heinz Schilling, "Confessionalization in the Empire: Religious and Societal Change in Germany between 1555 and 1620," in his Religion, Political Culture and the Emergence of Early Modern Society: Essays in German and Dutch History, tr. Stephen G. Burnett (Leiden: E. J. Brill, 1992), 222-32.

${ }^{48}$ There continued, however, to be a great deal of soul-searching on the civil and religious status of Jews within Protestant confessional states. See Johannes Wallmann, “The Reception of Luther's Writings on the Jews from the Reformation to the End of the 19th Century," Lutheran Quarterly 1 (1987): 81-83; Martin Friedrich, Zwischen Abwehr und Bekehrung. Die Stellung der deutschen evangelischen Theologie zum Judentum im 17. Jahrhundert, Beiträge zur historischen Theologie, no. 72 (Tübingen: J. C. B. Mohr [Paul Siebeck], 1988), 19-25; and Jacob Meijer, “Hugo Grotius' Remonstrantie," Jewish Social Studies 17 (1955): 91-104.

${ }^{49}$ The readiness of both Catholic and Protestant princes to defy an imperial commission which attempted to investigate an alleged Jewish conspiracy in 1606 in an effort to protect their Jewish subjects (and their own ruling authority thereby) illustrates just how much the situation for Jews had changed since the Peace of Augsburg. See Volker Press, "Kaiser Rudolf II und der Zusammenschluss der deutschen Judenheit. Die sogenannte Frankfurter Rabbinerverschwörung von 1603 und ihre Folgen," in: Alfred Haverkamp, ed. Zur Geschichte der Juden im Deutschland des späten Mittelalters und der frïhen Neuzeit, Monographien zur Geschichte des Mittelalters (Stuttgart: Anton Hiersemann, 1981), 270-71.

${ }^{50} J u d e n$ Schul, 540. 
mention the charge that the Jews sought to convert others to their religion, one of the questions that Margaritha and Josel of Rosheim disputed before Charles V. ${ }^{51}$ The only really important issues involving the magistrate that Buxtorf discussed were blasphemy and sedition, both overt and implied, in the synagogue liturgy and in the Talmud. ${ }^{52} \mathrm{He}$ acknowledged that Christian censors had been able to stamp out some of the worst offenses, eliminating for example parts of the Alenu prayer, but there was still more work to be done. He considered Polish authorities to be especially lax in their censorship of Jewish books. ${ }^{53}$ Censorship of Hebrew books and oversight of the Jewish book trade, however, was a responsibility that was shared by the magistrate and the clergy, if only because most Christian Hebraists were clergymen. What Buxtorf provided in Jewish Synagogue was, in effect, a checklist for censors who wished to review prayer books for inappropriate content. ${ }^{54}$

Buxtorf portrayed the Jews of his day as the spiritual descendants of those who had rejected Moses and the prophets. They were by no means a social or political threat to the Christian world order. Christian clergymen bore the greatest responsibility toward Jews because they had to be ready and able to explain the Christian gospel to them. They also had to be aware of blasphemy and sedition within Jewish religious literature so that they could better serve the magistrate as censors. Buxtorf had every reason to try and be as accurate as he could in presenting the Jewish point of view because missionary activity and censorial review required accurate information to be successful. ${ }^{55}$ The quest for accuracy in reporting the opposing theological views was, in fact, a hallmark of seventeenth-century theological polemics. Although theologians of all stripes engaged in vicious and often personal attacks, it was generally understood that an opponent could not be refuted unless his position was first properly understood. ${ }^{56}$ To aid ministers in arguing with the Jews, Buxtorf also provided a German translation of Calvin's tract Response to Questions and Objections of a Certain Jew, which he included as an appendix to Jewish Synagogue. 57

The publication of Jewish ethnographies had social repercussions for the Jews themselves, as the differing responses of Jewish leaders and intellectuals to Marga-

${ }^{51}$ Stern, Josel of Rosheim, 99-101. Although the rabbis actively discouraged Jews from proselytizing Christians, the talmudic laws governing conversion were technically still in force during Buxtorf's lifetime, and Buxtorf could easily have learned of them by reading Joseph Karo, Shulhan Aruk, Yore Deah, paras. 268-69. See Sigal, Emergence of Contemporary Judaism, 2:363, 565, n. 78.

${ }^{52}$ Buxtorf mentions a number of Jewish books that had either been censored or should have been censored in Juden Schul, 91, 206-7, 219-20, 223-27, 249, 460, 477-79.

${ }^{53}$ Ibid., 227-28. On the Polish authorities, see 219.

${ }^{54}$ See Stephen G. Burnett "Hebrew Censorship in Hanau: A Mirror of Jewish-Christian Coexistence in Seventeenth Century Germany," in The Expulsion of the Jews: 1492 and After, ed. Raymond B. Waddington and Arthur H.Williamson (New York: Garland, forthcoming).

${ }^{55} \mathrm{On}$ the importance of knowledge of Judaism to Christian missionaries, see Robert Chazan, Daggers of Faith: Thirteenth Century Christian Missionizing and Jewish Response (Berkeley: University of California Press, 1989),14-16. Yerushalmi, “The Inquisition and the Jews," 354, argues that Bernard Gui had a similar reason to strive for accuracy in the section on Judaism in his inquisitorial manual.

${ }^{56}$ Richard A. Muller, Post-Reformation Reformed Dogmatics, vol. 1: Prolegomena to Theology (Grand Rapids: Baker Book House, 1987),32.

${ }^{57}$ See Stephen G. Burnett, "Calvin's Jewish Interlocutor: Christian Hebraism and Anti-Jewish Polemics during the Reformation," Bibliothèque d'Humanisme et Renaissance (forthcoming). 
ritha's Entire Jewish Faith and to Buxtorf's Jewish Synagogue illustrate. The leaders of German Jewry learned of Margaritha's book even before it was printed, and they met in Worms to consider this new threat. Margaritha's disputation with Josel of Rosheim a short time later demonstrated the serious nature of the accusations he made against the Jews. His book had called into question not only the religious validity of Judaism, as many theologians had done before, but the social and political status of German Jewry. Margaritha made his charges at some personal risk, and like Pfefferkorn before him, he lived in fear that he would be murdered by vengeful Jews. ${ }^{58}$

Buxtorf's Jewish Synagogue, by contrast, caused no great stir when it appeared. A Latin translation of the book was printed twice in Hanau, a town near Frankfurt with both a Jewish community and Jewish press, and yet Buxtorf was able to hire two of Hanau's best Jewish printers in 1617 to help him print a rabbinical Bible in Basel. ${ }^{59}$ Between 1603, the year that Jewish Synagogue first appeared, and 1617, Buxtorf had extensive business dealings with Jewish printers and booksellers. Buxtorf's theological critique apparently had little or no effect upon his own interaction with Jews. ${ }^{60} \mathrm{~A}$ Jewish writer named Solomon Zvi Hirsch even quoted Buxtorf as an authority in his apologetic work, Yudischer Theriak (Hanau, 1615), to respond to an anti-Jewish calumny raised by his opponent, the convert Samuel Brenz. ${ }^{61}$ The first written response to Jewish Synagogue was penned in about 1616 by Leon Modena, a Venetian rabbi. Modena attempted to undercut the influence of Jewish Synagogue by replacing it with a shorter, but no less tendentious, explanation of Jewish customs and beliefs. He confided to Vincent Noghera, a Catholic theologian friend, that he wrote in order to refute Jewish Synagogue and to give "a true account of the fundamentals [of Judaism], leaving out those items which have been considered by our own people (by the intelligent men among them) as superstitious." 62 Modena thought that Jewish Synagogue was an affront and a hindrance to

${ }^{58}$ Kirn, Bild, 110. Throughout the Middle Ages Jewish law stated that informers were to be killed without mercy because they were a danger to the entire Jewish community of a locality. See Salo W. Baron, The Jewish Community: Its History and Structure to the American Revolution, 3 vols. (Philadelphia: Jewish Publication Society, 1942), 2: 220-23, 3: 174-75.

${ }^{59}$ Stephen G. Burnett, "Johannes Buxtorf and the Circumcision Incident of 1619," Basler Zeitschrift für Geschichte und Altertumskunde 89 (1989): 136-37.

${ }^{60}$ Jews in Germany and elsewhere were aware of Juden Schul before 1619. Both Leon Modena in Venice, and Eliahu Montalto had Latin copies of the book. Cf. Bernard Dov Cooperman, "Eliahu Montalto's 'Suitable and Incontrovertible Propositions': A Seventeenth-Century Anti-Christian Polemic," in Jewish Thought in the Seventeenth Century, ed. Isadore Twersky and Bernard Septimus, Center for Jewish Studies/Harvard Judaic Monographs, no. 6 (Cambridge: Harvard University Press, 1987), 476.

${ }^{61}$ Salman Zvi Hirsch quoted from a German copy in his book Yüdischer Theriak (Hanau, 1615; reprinted in Johannes Wülfer, Theriaca Judaica ad Examen Revocata (Nürnberg: Andreas Knorzen, 1681), chap. 1, sec. 21. The speed with which news of Brenz's Jüdischer Abgestreiffter Schlangenbalg (1614) spread among Jewish communities throughout Germany shows that Jews were aware of the danger that these "ethnographies" could pose for them, and they were able to communicate with each other fairly quickly if the need arose. See Burnett, "Hebrew Censorship in Hanau."

${ }^{62}$ Leone da Modena to Vincenzo Noghera, n.p., n.d, London: British Library MS OR. 5395, fol. 22, printed by Cecil Roth, "Leone da Modena and the Christian Hebraists of His Age," in Jewish Studies in Memory of Israel Abrahams, ed. Jewish Institute of Religion (New York: Press of the Jewish Institute of Religion, 1927; reprint ed., New York: Arno, 1980), 395. See Franz Kobler, ed., A Treasury of Hebrew Letters. Letters from the Famous and the Humble, 2 vols. (London: Farrar, Straus and Young, 1952), 2: 42021 , for the English translation quoted here. 
Christian social acceptance of Jews rather than a direct threat to Jews and Jewish communities. ${ }^{63}$

Margaritha and Buxtorf both used ethnographies in the service of theology in order to undermine the religious validity of Judaism. By describing Jewish life and religion as an outward expression of inward Jewish theological convictions these works served to contrast the Bible and the Talmud, always to the detriment of the latter. Martin Friedrich classified anti-Jewish polemics of this kind as Warnschriften, "warnings" concerning the dangers that Jews and Judaism posed for Christianity. ${ }^{64}$ Although Margaritha's Entire Jewish Faith and Buxtorf's Jewish Synagogue are similar in form and content, and share much the same underlying theology, they differ in their focus and audience, and they reflect very different political assumptions governing Jewish life within the empire. Margaritha sought the attention of German princes, demanding that they alter the status of the Jews within the Holy Roman Empire in order to free Christians from bondage to Jewish masters and to take some of the "comforts of the exile" away from the Jews. He wrote his book during the first years of the Reformation, and by demanding greater social disabilities for the Jews he followed in the footsteps of Pfefferkorn and anticipated Martin Bucer's discriminatory Cassel Advice (1538) and Martin Luther's harsh Jewish policy outlined in On the Jews and Their Lies (1543). At a time when Protestant princes, magistrates, and clergy were rethinking old policies and reshaping their societies in the wake of the Reformation, it was not surprising that Jewish policies too should be called into question. ${ }^{65}$ Margaritha's book had a sharp polemical edge in part because its author was involved in a personal struggle with his former brethren and feared that he might pay for his activities with his life.

Buxtorf, on the other hand, addressed a changed religious and political situation. Jewish settlement and life within German towns and principalities was accepted, or at least tolerated, by many Protestant secular and religious authorities. Buxtorf addressed his book primarily to a Protestant audience, and focused on Judaism as a religion and the rabbis as its theologians. ${ }^{66} \mathrm{He}$ sought to provide ministers with a thorough description and analysis of what the Jews actually believed and practiced in order to help them to write better missionary books and sermons. ${ }^{67}$ The only power that Protestant clergymen had over the Jews of early seventeenth-century Germany was the power of persuasion, and Buxtorf conscien-

${ }^{63}$ Cohen, "Modena," 298, 313-14.

${ }^{64}$ Friedrich, Zwischen Abwehr und Bekehrung, 46, n. 149.

${ }^{65}$ See Kirn, Bild, 70-80, and Jerome Friedman, The Most Ancient Testimony: Sixteenth-Century Christian-Hebraica in the Age of Renaissance Nostalgia (Athens, Ohio: Ohio University Press, 1983), 195-209.

${ }^{66}$ Buxtorf may in fact have had a Lutheran readership in mind. He reprinted a long quotation from Luther's Von den Juden und ihren Lügen (WA 53:480.30-481.22) in the last two pages of his introduction to Juden Schul, and he neglected to mention that the appendix had been written by John Calvin.

${ }^{67}$ Whether Jewish Synagogue can be considered a missionary work itself remains open to question. It contains no positive argument for the truth of Christianity, a condition which Chazan, Daggers of Faith, 14-16, considers essential for a true missionary book. Yet seventeenth-century Protestants often felt that they had fulfilled their obligation to persuade Jews to repent by demonstrating to their own satisfaction that Judaism was unbiblical. If God opened the eyes of individual Jews then they would repent and believe. See Friedrich, Zwischen Abwehr und Bekehrung, 51-52. 
tiously tried to reflect Jewish opinion accurately so that other scholars could forge effective counterarguments. Buxtorf thought that the only ways that Jews could endanger Christians were through their false doctrine, curses, and blasphemy, all of which could be controlled to a degree through an educated ministry and an alert magistrate. Although Buxtorf was not a professional theologian, he had been trained in theology, and he analyzed Judaism with the same theological tools that other theologians had developed for use against Catholics and Protestant heretics. Since Buxtorf was not a Jewish convert, his attack upon Judaism was more impersonal than Margaritha's had been. While both Margaritha and Buxtorf provided distorted mirrors of the Jews, Buxtorf's portrayal of Jewish faith and life is more accurate and complete, reflecting both his abilities as a scholar and his theological purpose. 